\title{
Managing complex MNEs: structural attributes of the MNE and expatriation strategies
}

Book or Report Section

Accepted Version

Lee, J. M. (2016) Managing complex MNEs: structural attributes of the MNE and expatriation strategies. In: Academy of Management Proceedings. Academy of Management. doi: https://doi.org/10.5465/AMBPP.2016.171 Available at https://centaur.reading.ac.uk/72645/

It is advisable to refer to the publisher's version if you intend to cite from the work. See Guidance on citing.

Published version at: http://proceedings.aom.org/content/2016/1/13284.abstract?sid=fe6b4383-3d1e-47d4-b59ad02ec3ebb300

To link to this article DOI: http://dx.doi.org/10.5465/AMBPP.2016.171

Publisher: Academy of Management

All outputs in CentAUR are protected by Intellectual Property Rights law, including copyright law. Copyright and IPR is retained by the creators or other copyright holders. Terms and conditions for use of this material are defined in the End User Agreement.

\section{www.reading.ac.uk/centaur}

\section{CentAUR}


Central Archive at the University of Reading

Reading's research outputs online 


\title{
MANAGING COMPLEX MNES: STRUCTURAL ATTRIBUTES OF THE MNE AND EXPATRIATION STRATEGIES
}

\author{
JONG MIN LEE \\ Henley Business School, University of Reading \\ Reading, RG6 6UD, United Kingdom
}

\section{INTRODUCTION}

The view of the multinational enterprise (MNE) as an interorganizational network of differentiated subsidiaries that command their own set of capabilities in host locations, rather than as a hierarchically run organization with mandated role playing subsidiaries, is now widespread in international business (IB) literature (Ghoshal \& Bartlett, 1990; Hedlund, 1986; Nohria \& Ghoshal, 1994). The network view of the MNE have brought about significant attention to the complex nature of the multinational organization, particularly in conjunction with the control and coordination issue (Ghoshal \& Bartlett, 1990). Having subsidiaries with their own resources and capabilities, MNEs may take advantage of diversity and multiplicity of knowledge from a variety of locations by allowing subsidiaries to have more active roles (i.e., initiatives) or legitimating their activities within the MNE (i.e., granting supportive attentions) (Bouquet \& Birkinshaw, 2008; Meyer, Mudambi, \& Narula, 2011). However, this may necessarily lead a loosening of central control of MNE headquarters (HQ) over subsidiaries, or a discount of the power differential between them, which in turn brings much more complex coordination issues into the MNE than the economic-based IB literature often suggested (Birkinshaw \& Hood, 1998; Doz \& Prahalad, 1991; Hedlund, 1986; Morgan, 2006).

In line with this, the parenting role of HQ such as control and coordination of subsidiary activities has become increasingly crucial in the MNE management. In particular, many MNEs now manage substantially enlarged organizational network in which a number of subsidiaries have dynamic interdependencies with each other as well as with their host location contexts (Meyer et al., 2011). Whereas advanced information and communication technology make it easier to monitor subsidiary activities and transfer knowledge across distance, many MNEs have begun to realize that managing such increasingly dispersed organizations often involves a greater deal of managerial difficulties, complexities, and costs than initially anticipated (Narula, 2014).

While recent literature has argued that HQ need to play more sophisticated parenting roles that enable them to benefit from diversity without being overwhelmed by the managerial challenges stemming from the diversity (Meyer et al., 2011), not many studies have yet explicitly explored this issue; how MNEs effectively manage a complex organizational network that consists of differentiated subsidiaries. In particular, several recent studies have paid specific attention to the complexity issues in MNEs such as external business network complexity (Nell \& Andersson, 2012), reconfiguration of MNE activities both within and across firm boundaries (Larsen, Manning, \& Pedersen, 2013; Mudambi, 2008), and technological and geographical dispersion-bandwidth paradox (Narula, 2014), but very few have paid attention on the managerial complexity stemming from the internal network structure of the MNE.

This study aims to fill this research gap by examining the internal network structure of the MNE as well as the influence of structural attributes on the management of the MNE. Specifically, based on the conceptualization of the MNE as an interorganizational network (Ghoshal \& Bartlett, 1990), we advance three structural attributes of the MNE internal network, 
such as multinationality (the breadth of international activities), power structure (the degree of power distribution among MNE subunits), and regional dependence (the degree to which MNE activities are concentrated on a certain region), that originate from the differentiated composition of the MNE's subsidiary portfolio, and further examine their influences on expatriation strategies that play an increasingly crucial role in managing complex MNEs. While expatriation has been a key mechanism for HQ to effectively fulfill parenting activities across the MNE network (Edström \& Galbraith, 1977; Harzing, 2001a), its roles as an extended form of HQ control (Boyacigiller, 1990; Egelhoff, 1984) and as an efficient intermediary to transfer firm-specific knowledge across the MNE network (Björkman, Barner-Rasmussen, \& Li, 2004) have become more important in recent MNEs that manage a complex portfolio of multiple subsidiaries. Apart from prior literature that has typically examined the expatriate staffing from the subsidiary perspective, this study examines the expatriation strategies from the perspective of the MNE.

\section{THEORETICAL BACKGROUND AND HYPOTHESIS DEVELOPMENT}

\section{The MNE as an interorganizational network and Structural attributes}

Building on the conceptualization of the MNE as an interorganizational network, Ghoshal and Bartlett (1990) has systematically explained the complex nature of the MNE. In this view, an MNE is an 'internally differentiated network' that lies between 'unitary hierarchy' and 'federative network' (Warren, 1967), in which some level of hierarchical authority (of parent firm or MNE-HQs) coexists with significant local autonomy (of subsidiaries), and in which interdependencies among organizational units tend to be reciprocal as well as sequential (Ghoshal \& Bartlett, 1990; Ghoshal \& Nohria, 1989). In line, the MNE is conceptualized as a 'network of exchange relationships' between different sub-organizations that are collectively embedded in a 'structured context' (Homans, 1974) upon the belief that interactions among MNE subunits can be best explained by the level of resource exchange, and that such internal exchange relationships within the MNE are largely influenced by the structural characteristics that continually restructure organizational resource configurations (Benson, 1975; Ghoshal \& Bartlett, 1990; Zeitz, 1980).

Resource configuration in MNEs has been traditionally rationalized from an economic perspective, typically assuming the rational, self-interested decision making (e.g., Buckley \& Casson, 1985; Dunning, 1981; Hennart, 1982). However, such economic explanation usually underrated the crucial influence of social structure and exchange relations within the MNE on resource allocation decisions (Granovetter, 1985) as well as the influence of surrounding institutional environment on the behavior of organizations (Meyer \& Scott, 1983). From institutional theoretical perspective, organizations compete not just for resources, but also for political power and institutional legitimacy (Dimaggio \& Powell, 1983). Given the unique organizational form of the MNE whose constituent units are embedded in different national environments that involve different institutional needs for legitimacy (Westney, 1993), MNE HQs need to cope with a variety of strong needs for local legitimacy in each host country environment, while dealing with another strong demand for efficiency within the whole MNE network (Bartlett \& Ghoshal, 1989; Meyer et al., 2011). Therefore, the managerial decision and behavior of the MNE are subjected to be influenced by the structural composition of the MNE network such as the degree of geographical dispersion and the degree of heterogeneity of host locations (Ghoshal \& Bartlett, 1990). 
Moreover, the flow of resources within an interorganizational network is largely affected by the distribution of power within the network (Benson, 1975; Ghoshal \& Bartlett, 1990). Each MNE subunit including HQs has respective power within the network upon their exchange relations with other subunits (Cook, 1977; Pfeffer \& Salancik, 1978), and such power relations affect the resource configuration as well as other managerial decisions. This implies that HQsubsidiary relations within the MNE are likely to vary widely from one subsidiary to another, and that continuous power-bargaining processes among subunits happen inside the MNE which sequentially influence the structure and behavior of the organization (Birkinshaw \& Hood, 1998; Hedlund, 1986).

In sum, conceptualization of the MNE as an interorganizational network provides a useful theoretical lens through which to examine internally differentiated organizational system such as MNEs (Ghoshal \& Bartlett, 1990). Indeed, the heterogeneity of MNE subunits in their roles, relations, and local contexts increases the managerial complexity of HQs, and further differentiates internal coordination mechanism to match the variety of subunit attributes (Bartlett \& Ghoshal, 1989; Ghoshal \& Bartlett, 1990; Ghoshal \& Nohria, 1989). Therefore, it is crucial for HQ to consider the structural attributes of the MNE network that collectively reflect various internal dynamics and different subunit contexts. In this study, we contend that, in order to understand the managerial complexity faced by MNE-HQ that manages a large portfolio of differentiated subsidiaries, it is essential to understand how the portfolio, in other words, the internal network of the MNE, looks like.

\section{Multinationality}

Expatriation provides HQ with an essential means for parenting activies, especially in terms of control and knowledge transfer (Boyacigiller, 1990; Delios \& Beamish, 2001). In particular, expatriation is an exclusively useful means for nascent MNEs that, due to their little experience and insufficient knowledge of foreign operations, are more vulnerable to the challenges of foreign operations (Johanson \& Vahlne, 2009; Zaheer, 1995). In the initial period of foreign expansions, MNEs often attempt to transplant their home country business to overseas operations in order to overcome the liability of foreignness by utilizing intensive expatriation (Beamish \& Inkpen, 1998; Yoshihara, 2001). Therefore in the early period of international expansion, in other words, when MNEs have only few subsidiaries in a small number of countries, intensive expatriation is a reasonable strategy for both HQ and subsidiaries.

However, when the level of multinationality increases beyond a certain point, HQs are likely to confront with practical difficulties in maintaining intensive expatriation due to their limited managerial resources (Hutzschenreuter et al., 2011; Penrose, 1959). MNE-HQs with high level of multinationality need to allocate substantial managerial resources in coordinating overall MNE network, and this eventually challenges HQ to remain in tight control of all subsidiaries through personnel mechanisms such as expatriation (Hutzschenreuter et al., 2011). Therefore, as the level of multinatinality increases, MNE-HQs are incited to formulate their control and coordination system less dependent on personnel mechanism, but more focused on bureaucratic mechanism that involves rules, programs, and procedures (Doz \& Prahalad, 1991; Galbraith, 1973) and routinize their expatriation strategy based on the accumulated experiences and knowledge from their successive expansions and multilateral operations.

In sum, as the level of multinationality increases, MNE-HQs will generally reduce their expatriation level in subsidiaries partly due to the limitation of managerial resources and partly 
owing to the incentive of benefiting from local diversity. Therefore, hypothesis 1 is formed as follows:

Hypothesis 1: The level of MNE multinationality has a negative relationship with the overall expatration level in subsidiaries

\section{Power structure}

In an interorganizatinal network, the flow of resources is largely influenced by the distribution of power within the network, which is an antipode of dependency in exchange relations (Benson, 1975; Ghoshal \& Bartlett, 1990). Power within the network accrues to organizational members that possess and control critical resources required by others (Aldrich, 1976; Pfeffer \& Salancik, 1978). Thus organizational members of the network strive to acquire valuable resources to reduce their dependence on others while increasing other's dependence on themselves. This power-bargaining process is not uncommon in many recent MNEs. Many subsidiaries now have retained substantial knowledge and resources accumulated from their local operations and external networks, and thereby, acquired considerable strategic independence (Birkinshaw \& Hood, 1998; Rugman \& Verbeke, 2001). In consequence, many subsidiaries become able to exercise considerable bargaining power within the MNE network to influence resource distribution of the MNE, and many MNEs now have more federative power structure in which all subunits, including HQ, are involved in a perpetual power bargaining process (Andersson, Forsgren, \& Holm, 2007; Mudambi \& Navarra, 2004).

In line with this, MNEs are concerned about agency problems caused by the misalignment of organizational goals and economic incentives between HQ and subsidiaries (Jensen \& Meckling, 1976; O'Donnell, 2000). While this agency problem is more likely to occur from the subsidiaries with high bargaining power within the MNE network (Mudambi \& Navarra, 2004), HQ can monitor their behaviors by deploying expatriates that serve as an extended form of HQ control and supervision (Boyacigiller, 1990; Egelhoff, 1984; Tan \& Mahoney, 2006).

Therefore, if an MNE has more oligopolistic power structure in which power in the MNE network is highly concentrated on a small number of subsidiaries, there will be stronger power bargainings between HQ and subsidiaries, compared with MNEs that have more egalitarian power structure where power is more evenly distributed among subsidiaries.

In consequence, MNEs that manage an organizational network with oligopolistic power structure are more likely to concern about agency problems, and therefore, generally utilize more intensive expatriation over their subsidiaries to secure their control. Therefore, hypothesis 2 is formed as follows:

Hypothesis 2: Oligopolistic power structure has a positive relationship with the overall expatration level in subsidiaries

\section{Regional dependence}

While much of the IB literature uses the country as the relevant environment factor, some scholars have paid specific attention to the regional characteristic, contending that the reality of international business orchestrated by MNEs can be better explained by a regional 
focus (Rugman \& Oh, 2010, 2013; Rugman \& Verbeke, 2004). Indeed, the regional attribute of the MNE captures the collective influence of the external environment on MNE management, which is often missed out by country-focused parameters such as multinationality. For instance, MNEs that have the same number of operating countries may have completely different regional dependence upon the geographical dispersion of operating countries. Given that countries that belong to the same region often not only have geographical proximity but also share similar culture, language, and formal and informal institutions (Ghemawat, 2007; Rugman \& Oh, 2013), the managerial complexity perceived by MNE-HQs tends to be largely different upon the regional dependence of MNE activities, and therefore, such regional attribute will influence MNE management as well as expatriation strategies.

If an MNE operation is highly dependent on a certain region, in other words, the majority of their subsidiaries are concentrated in a specific region rather than widely dispersed across many regions, this MNE is likely to accumulate much knowledge and information about the region, and generally have less uncertainty in local operations, compared with MNEs that have more dispersed regional presences. Therefore, such MNE is likely to have less managerial complexity as its activities mostly take place in the same region.

Therefore, MNEs that have high regional dependence on a specific region are less likely to utilize intensive expatriation in their subsidiaries, which usually incurs high managerial costs (Shaffer, Harrison, \& Gilley, 1999). Therefore, hypothesis 3 is formed as follows:

\section{Hypothesis 3: Regional dependence on a certain region has a negative relationship with the overall expatration level in subsidiaries}

\section{METHOD AND RESULTS}

We examine the hypotheses using Korean MNEs. The data were collected from a variety of reliable sources such as national agencies and international institutions. A cross-sectional MNE dataset was built by aggregating information from '2011/2012 Overseas Korean Business Directory' (hereafter 'directory') published by Korea Trade-Investment Promotion Agency (KOTRA) and 'Kis-value' database provided by National Information and Credit Evaluation (NICE), both of which are credible information providers accredited by Korean government.

The overall expatriation level of the MNE was measured by the average of expatriation rate in constituent subsidiaries. The expatriation rate, which is the ratio of the number of expatriates to the total number of subsidiary employees, is a common measurement that has been widely used in prior literature (e.g., Boyacigiller, 1990; Gaur et al., 2007; Gong, 2003; Peng \& Beamish, 2014). Multinationality was measured by counting the number of operating countries (e.g., Kogut \& Singh, 1988; Reuer \& Leiblein, 2000). To measure the power structure and the regional dependence of the MNE network, we devised an index modifying the HerfindahlHirschman Index (HHI) which originally measures the market structure using the market share of firms (Herfindahl, 1950; Hirschman, 1945; Miller, 1982). We used the share of relative subsidiary size to the whole MNE to measure the power structure of the MNE network, while we used the number of subsidiaries in a certain region as a regional share to measure the regional dependence of the MNE. We included a number of control variables from both firm and environmental levels in our analysis. The results of the OLS regressions support all the hypothesized relationships. 


\section{DISCUSSION AND CONCLUSION}

Many contemporary MNEs face a great deal of managerial complexities as they manage a large portfolio of multiple differentiated subsidiaries. This study contends that the internal network structure is an important factor that determines the degree of complexities involved in the management of the MNE network, and hence, affects the managerial decisions such as expatriation.

The empirical findings of this study provide an important implication on human resource strategies in complex MNEs. The role of expatriation as a control and coordination mechanism and an agent of knowledge transfer from and to HQ becomes more important in modern MNEs with rapidly growing affiliate networks. Given the trade-offs of expatriation, such MNEs face a managerial dilemma whether they need to augment their expatriate utilization or reduce their reliance on expatriate managers and cultivate local talents. This is an important decision associated with the long-term competitive advantages of the firm as competent human resources, both expatriates and local talents, are hardly equipped in the short run upon the necessity. Our results suggest that to understand how MNE internal networks is composed is crucial for such decision making.

By taking a pluralistic rather than a unitary theoretical perspective, this study aims to obtain richer insights into the complex nature of expatriate utilization. Moreover, apart from most previous expatriate staffing literature, we examine expatriation strategies from the perspective of the MNE as a whole, providing useful extensions and implications to current expatriate staffing literature.

"REFERENCES AVAILABLE FROM THE AUTHOR(S)" 